7 (2016)

DOI: $10.18276 /$ rk.2016.7-19

Iwona Radziszewska

Uniwersytet Mikołaja Kopernika w Toruniu

\title{
O literaturze tatarskiej w aspekcie międzynarodowym
}

Zbiór artykułów zatytułowany Estetyczne aspekty literatury polskich, biatoruskich i litewskich Tatarów (od XVI do XXI w.), który ukazał się w naukowej serii wydawniczej Colloquia Orientalia Bialostocensia jako jej czternasty tom, jest pokłosiem Międzynarodowej Konferencji Naukowej, firmowanej tym samym tytułem, która odbyła się w Białymstoku i Sokółce w dniach 14-15 listopada 2014 roku. Brali w niej udział poloniści, slawiści, orientaliści, historycy i socjologowie. Ogrom perspektyw badawczych prezentowanych przez ekspertów różnych dziedzin zaowocował interdyscyplinarnym ujęciem tematu, którym miało być religijne piśmiennictwo tatarskie sięgające XVI wieku, a także współczesna działalność literacka i reporterska społeczności tatarskiej żyjącej obecnie w granicach Polski, Litwy i Białorusi.

Międzynarodowy i wieloaspektowy charakter tomu podkreśla już sam tytuł i wprowadzenie redakcyjne, zaprezentowane w trzech językach: polskim, angielskim oraz rosyjskim. Ogromną zaletą publikacji jest również fakt, że czytelnik otrzymuje ją w niespełna rok po sesji naukowej.

Całość podzielono na trzy części, które odnoszą się kolejno do: rękopisów Tatarów Wielkiego Księstwa Litewskiego, współczesnej literatury Tatarów Polskich oraz Tatarów w kontekście literackim i kulturowym.

Część pierwszą, poświęconą religijnym rękopisom tatarskim, otwiera artykuł Shirin Akiner An Eclectic Literary Monument: The Religious Literature of the Tatars of Belarus, Lithuania and Poland. Autorka wychodzi od krótkiego omówienia tła historycznego, początków tworzenia opisywanej literatury religijnej oraz rodzajów tworzonych ksiąg, by następnie skupić się na jednej z nich, kitabie - księdze najbardziej zróżnicowanej treściowo. Uwaga skoncentrowana jest głównie na tekstach biblijnych wplecionych w treść kitabów, które zaprezentowane zostały na przykładzie znanego nauce British Library Kitab (Akiner, 2009) z przytoczeniem zawartej w nim historii stworzenia świata opartej na Księdze Rodzaju a zestawionej z Bibliq Wujka. 
Ważnym, bo prezentującym nowe odkrycie, jest kolejny artykuł, Nieznany rękopis polskiego przekładu Koranu, autorstwa trójki badaczy: Czesława Łapicza, Joanny Kulwickiej-Kamińskiej oraz Artura Konopackiego. Zaznajamiają oni czytelnika z nieznanym dotąd fragmentem polskiego przekładu Koranu pochodzącym, jak ustalono na podstawie kroju pisma i realizacji graficznej wybranych głosek, z pierwszej połowy XIX wieku. Rękopis należy do prywatnego zbioru dokumentów podworskich z Czomborowa, które ocalały z wojennej pożogi. Historia ta przywodzi na myśl słowa Wolanda z powieści Mistrz i Matgorzata Michaiła Bułhakowa: „rękopisy nie płoną", a przynajmniej, jak w tym przypadku, nie w całości. Prezentowany fragment to 26 najkrótszych sur, czyli, jak wyliczyli autorzy, nieco ponad 5\% treści Koranu. Jednak już ten niewielki fragment okazał się niezwykle cenny, ponieważ pozwolił na porównania z innymi, znanymi nauce manuskryptami. Analiza filologiczna wykazała zbieżności z poznańską edycją filomackiego przekładu Koranu, co pozwoliło autorom na postawienie hipotezy, jakoby przekład z Czomborowa był kopią przekładu filomackiego. Charakter pisma natomiast badacze uznali za zbieżny z ręką imama Ibrahima Januszewskiego, korektora Tefsiru z Olity, czyli tekstu koranicznego z interlinearnym jego „objaśnieniem” umieszczanym ukośnie między wierszami oryginału. Być może kolejna edycja konferencji poświęconej literaturze polskich, białoruskich i litewskich Tatarów odkryje nowe fakty o zagadkowym rękopisie.

Jak ważne są takie odkrycia, nie tylko dla wąskiego grona kitabistów, ale ogólnie dla badań nad tekstami staropolskimi, uświadamia tekst Anetty Lutto-KamińskiejZnaczenie literatury Tatarów Wielkiego Księstwa Litewskiego dla badań lingwistycznych nad polskimi tekstami dawnymi. Autorka zauważa, że religijna literatura Tatarów Wielkiego Księstwa Litewskiego może być traktowana jako tekst źródłowy w badaniach nad językiem polskim, choć należy podkreślić, że nie tylko ten język reprezentowany jest w zabytkach tatarskich. W zależności od przyjętej perspektywy badawczej, synchronicznej czy diachronicznej, na podstawie manuskryptów tatarskich można analizować cechy językowe okresu, z którego tekst pochodzi, wyekscerpować cechy reprezentatywne dla danej epoki lub zaobserwować rozwój polszczyzny, zjawiska przemijające i nadchodzące zmiany językowe. Prócz wiedzy historycznojęzykowej podczas lektury rzeczonych źródeł zyskać można dodatkowo wiedzę kulturową na temat funkcjonowania dwóch kręgów religijnych: chrześcijańskiego i muzułmańskiego na ziemiach dawnego Wielkiego Księstwa Litewskiego. Interakcje środowiskowe wpłynęły bowiem na przenikanie do tatarskich ksiąg tekstów, takich jak szesnastowieczna apokryficzna Historyja barzo cudna... o stworzeniu nieba i ziemie Krzysztofa Pussmana (1890), której dwie polskie edycje zestawiono 
$\mathrm{w}$ artykule z fragmentem tego utworu zapisanego na kartach osiemnastowiecznego Kitabu Milkamanowicza.

Kolejny tekst, Exorcism Rites from khamail-manuscripts of Lipka Tatars Dmitry’ego Sevruka, jeszcze głębiej wchodzi w zawartość treściową tatarskich ksiąg religijnych, przedstawia bowiem oryginalne fragmenty chamaitów, tatarskich modlitewników, które autor interpretuje jako egzorcyzmy. Oryginalny tekst zapisany arabskim alfabetem uzupełniony został transkrypcją na alfabet łaciński oraz przekładem na język angielski. Odbiór cennego materiału źródłowego zakłóca tu jednak użyta przez autora w odniesieniu do omawianej grupy społecznej nazwa Lipka Tatar. O błędnym stosowaniu nazwy Lipkowie pisał m.in. w latach osiemdziesiątych minionego wieku Jacek Sobczak (1984) w opracowaniu Potożenie prawne ludności tatarskiej w Wielkim Księstwie Litewskim ${ }^{1}$. Sevruk powołuje się na termin "Lipka” zamieszczony w Encyclopaedia of Islam z 1986, w której hasło to opracowali Zygmunt Abrahamowicz i Jan Reychman (The Encyclopaedia of Islam, 1986: 765-767). Obecnie encyklopedia w trzech edycjach dostępna jest online na stronie wydawnictwa Brill (www.brillonline.com). Jest ona uzupełniana i aktualizowana cztery razy do roku, co daje szansę na wprowadzenie zmian w prezentowanym przez wydawnictwo haśle. Kontakt z redakcją i podjęcie działań w kwestii rozprzestrzeniania zawartego w rzeczonej encyklopedii hasła „Lipka” mógłby zapobiec dalszemu przedrukowywaniu dawnego opracowania terminu w obecnej formie oraz bezkrytycznemu korzystaniu z wymienionego źródła przez kolejnych badaczy. Tym bardziej, że termin użyty przez autora w oryginalnym tytule artykułu nie został dosłownie przetłumaczony i w polskim, jak też rosyjskim, streszczeniu zastąpiono go określeniem, odpowiednio: Tatarzy Wielkiego Księstwa Litewskiego oraz Tamapbl Великого княжества Литовского.

Artykułem zamykającym pierwszą część tomu jest tekst Magdaleny Lewickiej Identyfikacja $i$ analiza tekstologiczno-filologiczna arabskiej warstwy językowej stron 478-485 Tefsiru z Olity (1723), zawierający analizę arabskojęzycznego tekstu wraz z jego (staro)polskim i/lub (staro)białoruskim tłumaczeniem, co umieszczono na wybranych kartach rękopisu, który był przedmiotem badań w Projekcie flologiczno -historycznego opracowania oraz krytycznego wydania tzw. tefsiru Tatarów Wielkiego Księstwa (pierwszego przektadu Koranu na język stowiański) realizowanym przez

1 „Błędne jest też nadawanie Tatarom mieszkającym na Litwie miana Lipków. Zaczerpnięty ze źródeł tureckich termin Lipkowie był wprawdzie używany na określenie ludności tatarskiej, ale dopiero w XVII w. i to wyłącznie w odniesieniu do Tatarów mieszkających w Koronie - na Podolu." (Sobczak, 1984: 4). 
zespół badawczy pod kierownictwem dr. hab. prof. UMK Czesława Łapicza (www. tefsir.umk.pl).

Kolejną część tomu poświęcono współczesnej literaturze tatarskiej i jej twórcom. Czytelnikowi przyblizzone zostają: zaledwie szkicowo postać Stanisława Kryczyńskiego (Jan Tyszkiewicz, Kilka uwag o pisarstwie Stanistawa Kryczyńskiego), przede wszystkim historyka, autora pierwszej monografii poświęconej Tatarom polsko-litewskim: Tatarzy litewscy. Próba monografii historyczno-etnograficznej (Kryczyński, 1938), oraz znacznie dokładniej postać Selima Chazbijewicza (Светлана Червонная, Поэзия и журналистика Селима Хазбиевича) politologa, publicysty z bogatym dorobkiem poetyckim. Poezja obu: Kryczyńskiego i Chazbijewicza, jak również wiersze innych tatarskich (Musa Czachorowski, Michał Adamowicz) i nietatarskich (Mieczysław Czajkowski) poetów, cytowane są również przez Macieja Dajnowskiego w kolejnym tekście Fantazmat Wielkiego Stepu we wspótczesnej poezji Tatarów polskich, omawiającym częsty w poezji tatarskiej motyw stepu.

Artykułem zamykającym część drugą, który mógłby również otwierać ostatnią część publikacji, jest tekst Michała Łyszczarza - Spoteczny wymiar wspótczesnej poezji polskich Tatarów, w którym poezja oraz jej twórcy poddani są analizie socjologicznej, a autor dowodzi roli poezji jako czynnika podtrzymującego tożsamość etniczną społeczności tatarskiej.

Trzecia część tomu Tatarzy - kontekst literacki i kulturowy zawiera treści zróżnicowane tematycznie. Jeden z artykułów tej części, który ukazuje Tatarów w tytułowym kontekście kulturowym i literackim, to Tatarzy Henryka Sienkiewicza. Jego autorka, Jolanta Sztachelska, wykazuje, że polski noblista nader często umieszczał w swej twórczości bohatera Tatara. Bogate cytaty z dorobku pisarza kreślą portret Tatarów stworzony przez Henryka Sienkiewicza, który, jak chcą niektórzy, sam ma korzenie tatarskie. Czy motywy tatarskie w sienkiewiczowskiej prozie mają związek z rodowodem mistrza, pozostaje jednak kwestią otwartą.

Pozostałe teksty części zamykającej tom Studiów Tatarkkich traktują o literaturze i muzułmańskich twórcach z innych części świata: z Bośni (Marek M. Dziekan, Żcie i dzieto bośniackiego pisarza muzutmańskiego Muhameda Hevaiego Uskufiego (XVII w.)), Turkmenistanu (Николай Васькив, „На все взгляни, осмысли все”. Мотивы и образы поэзии Матымгулы Пырагы) i Chanatu Kazańskiego (Ляйсан Бадертдинова, Татарская литература периода Казанского ханства: исследования и исследователи). Mówią o nowoczesnej arabskojęzycznej poezji marokańskiej (Sergii Rybalkin, Modern Moroccan Arabic Poetry: Its Beginnings and Development), ale także o folklorze (Лилия Габдрафикова, Татарский фольклор как основа национального этикета) i modzie tatarskiej (Anna Cudowska, Wptywy 
tatarskie w modzie polskiej od XVI do XIX wieku), co z jednej strony jest ciekawym tłem, ale jednocześnie wydaje się zbyt szerokim ujęciem tematu jak na tom poświęcony, zgodnie z jego tytułem, estetycznym aspektom literatury Tatarów Wielkiego Księstwa Litewskiego.

Publikacja przybliża piśmiennictwo religijne mniejszości tatarskiej oraz sylwetki konkretnych twórców tatarskich, stąd zapewne, spójnie z zawartością, okładkę książki zdobią zarówno wizerunki osób, jak i reprodukcja kart rękopisu. Brakuje niestety informacji, jaki rękopis umieszczono na okładce oraz kim są postaci z widniejących na niej fotografii. $Z$ podjętych indywidualnych poszukiwań w podanym przez autorów źródle, czyli zbiorach Narodowego Archiwum Cyfrowego, wynika, że wykorzystano wizerunki trzech zasłużonych Tatarów: Olgierda Najman-Mirzy Kryczyńskiego, Jakuba Szynkiewicza i Alego Ismaila Woronowicza, których sylwetki nie zostały zaprezentowane $\mathrm{w}$ tomie.

Podsumowując, zaletą publikacji Estetyczne aspekty literatury polskich, biatoruskich i litewskich Tatarów (od XVI do XXI w.) jest przemyślany układ, szczególnie dwóch pierwszych części tomu, które kolejno wprowadzają w poszczególne zagadnienia związane z rękopiśmienną spuścizną Tatarów polsko-litewsko-białoruskich. Koncept wydaje się być realizowany w kolejnych punktach: wstęp, znane fakty, nowe odkrycia, ich znaczenie dla nauki, oryginalne treści rękopisów, współcześni twórcy tatarscy oraz varia, jednak warto byłoby zmienić objętościowe proporcje kolejnych części tomu tak, aby te poświęcone bezpośrednio rękopisom, literaturze religijnej oraz twórcom literackim i działaczom ważnym dla społeczności tatarskiej były obszerniejsze niż część opisująca tematy pokrewne. Każde z prezentowanych przez poszczególnych autorów zagadnień jest jednak na tyle interesujące, że omawiany tom serii wydawniczej Colloquia Orientalia Bialostocensia może stanowić ciekawą propozycję lektury zarówno dla zorientowanych w tematyce badaczy przedmiotu, jak i przypadkowych czytelników, którzy właśnie od tej publikacji rozpoczną przygodę z tatarską mniejszością dawnego Wielkiego Księstwa Litewskiego, jej dawnym piśmiennictwem religijnym, jak i współczesną poezją. 


\section{Bibliografia}

Akiner, Shirin. Religious Language of a Belarusian Tatar Kitab. A Cultural Monument of Islam in Europe. Wiesbaden: Harrassowitz Verlag, 2009.

Estetyczne aspekty literatury polskich, biatoruskich i litewskich Tatarów (od XVI do XXI w.). Red. Grzegorz Czerwiński, Artur Konopacki. Białystok: Wydawnictwo Uniwersytetu w Białymstoku, 2015.

Kryczyński, Stanisław. Tatarzy litewscy: próba monografii historyczno-etnograficznej, Rocznik Tatarski 3 (1938).

Pussman, Krzysztof. Historyja bardzo cudna o stworzeniu nieba i ziemi, 1551. Wyd. Zygmunt Celichowski. Kraków: Akademia Umiejętności, 1890.

Sobczak, Jacek. Potożenie prawne ludności tatarskiej w Wielkim Księstwie Litewskim. Warszawa-Poznań: PWN, 1984.

The Encyclopaedia of Islam. Vol. 5 (Khe-Mahi). Eds. Clifford Edmund Bosworth, Emeri van Donzel, Bernard Lewis, Charles Pellat. Leiden: E.J. Brill, 1986.

www.brillonline.com [dostęp: 9.09.2016].

www.tefsir.umk.pl [dostęp: 9.09.2016].

\section{About Tatar Literature in International Context}

\section{Summary}

The following paper offers an overview of the volume "Aesthetic Aspects of the Literature of Polish, Belarusian and Lithuanian Tatars (16th-21st Century)". The publication contains the lectures of from the International Conference which was devoted to Tatar literature and culture, held in Białystok and Sokółka from 14th to 15th November 2014. The texts written in Polish, English and Russian are grouped in three chapters: Manuscripts of the Tatars of the Grand Duchy of Lithuania, Contemporary literature of Polish Tatars and The Tatars - literary and cultural context. Each of them presents interesting facts about unique (copied and compiled\} religious manuscripts: kitabs, khamails, tefsirs, and articles about Tatar essayists, journalists and poets, expanding the knowledge about the Tatars community.

Keywords: comparative literature, Tatars of the Grand Duchy of Lithuania, Tatar literature, literature history, Islam, Oriental studies in Poland, kitabistics

Słowa kluczowe: literatura porównawcza, Tatarzy Wielkiego Księstwa Litewskiego, literatura tatarska, historia literatury, islam, polska orientalistyka, kitabistyka 